\title{
Salt/Sodium Intake Estimation in Children and Adolescents of Costa Rica
}

\author{
Hilda Núñez-Rivas ${ }^{1}$, Ileana Holst-Schumacher ${ }^{*}$, Adriana Blanco-Metzler ${ }^{1}$,

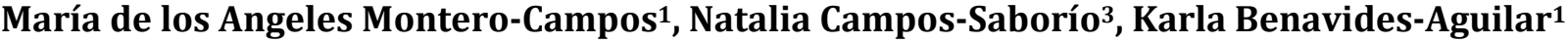

\author{
${ }^{1}$ Unit of Health and Nutrition of the Costa Rican Institute of Research and Education on Nutrition and Health (INCIENSA), \\ Tres Ríos, Costa Rica \\ ${ }^{2}$ Faculty of Microbiology, University of Costa Rica (UCR) and Research Center for Hematology and Related Disorders (CIHATA), \\ San José, Costa Rica \\ ${ }^{3}$ Distance State University (UNED) of Costa Rica, San José, Costa Rica \\ Email: hnunez@inciensa.sa.cr, ablanco@inciensa.sa.cr, kbenavides@inciensa.sa.cr, *ileana.holst@ucr.ac.cr, \\ nataliacampos07@yahoo.com, mariamonteroc54@gmail.com
}

How to cite this paper: Núñez-Rivas, H., Holst-Schumacher, I., Blanco-Metzler, A., de los Angeles Montero-Campos, M., Campos-Saborío, N. and Benavides-Aguilar, K. (2020) Salt/Sodium Intake Estimation in Children and Adolescents of Costa Rica. Food and Nutrition Sciences, 11, 919-941. https://doi.org/10.4236/fns.2020.1110065

Received: August 31, 2020

Accepted: October 20, 2020

Published: October 23, 2020

Copyright (c) 2020 by author(s) and Scientific Research Publishing Inc. This work is licensed under the Creative Commons Attribution-NonCommercial International License (CC BY-NC 4.0). http://creativecommons.org/licenses/by-nc/4.0/ cc) (i) (8) Open Access

\begin{abstract}
The objectives of this study were to estimate sodium intake and to identify the main dietary sources of this nutrient in young people. Cross-sectional study performed in 2685 students from 64 schools and high-schools of Costa Rica. A food frequency survey was applied to study the food and beverage intake habits of the participants. The average daily sodium intake for children and adolescents 7 to 18 years of age was $3214 \mathrm{mg}$. Around $97 \%$ of the students had sodium intakes $>2300 \mathrm{mg}$ per day with significant differences by age subgroup, sex and nutritional status due to excess body weight ( $\mathrm{p}<$ 0.001 ). The average sodium density of the diet was $1698 \mathrm{mg}$ sodium/1000kcal, and the average addition of salt to the food was $445 \mathrm{mg}$ of sodium (1.1 grams of salt). Including the amount added to the served food, the average sodium intake for children and adolescents from 7 to 18 years of age increased to $3434 \mathrm{mg}$ and the overall average sodium density increased to $1821 \mathrm{mg}$ of sodium $/ 1000 \mathrm{kcal}$, maintaining significant differences by age subgroups $(\mathrm{p}<$ 0.001). These results justify carrying out social marketing campaigns that include educational processes with sense and meaning for children, adolescents and families, in such a way that these groups of the population become motivated to modify gradually their eating habits, such as reducing the use of sauces, seasonings and salt in food preparation and at the table. If the habit of adding salt to the served food is gradually reduced or avoided, the children and adolescents in Costa Rica could decrease the intake of salt per day from 1 to 2 grams. This decrease could be even more effective if youngsters additionally would remove the intake of sauces, contributing in this way to achieve the maximum salt intake recommendation ( $5 \mathrm{~g}$ per day).
\end{abstract}




\section{Keywords}

Salt, Sodium Intake, Children, Adolescents, Costa Rica

\section{Introduction}

In Costa Rica, there are no data on sodium intake in children and teenagers or on the prevalence of high blood pressure in these populations. Scientific literature shows that about $90 \%$ of the American population with ages from 6 to 18 years consumes excess of sodium in the diet [1] and that approximately $11 \%$ of youth from 8 to 17 years old have blood pressure above the normal range for their age, sex and height [2], which increases the risk of high blood pressure in adulthood [3].

However, it is known that a decrease in sodium intake can reduce blood pressure in young people and adults [4], so first is essential to know the intake of this nutrient among children and teenagers and second, if it is excessive, reducing, since taste preferences acquired during childhood can influence dietary preferences in adulthood [5].

There are no internationally available data on the sodium requirement for children and teenagers. Their reference values are based on the collected values for adults and taking into consideration the differences in body weight and growth factors. As reported by the Institute of Medicine [6], these factors are calculated according to the proportional increase in the protein requirement for growth and maintenance [7].

The study by Strohm et al. (2018) [7] estimated the values for sodium intake in children and teenagers based on the reference values proposed by the German Nutrition Society, the Austrian Nutrition Society and the Swiss Nutrition Society [8]. The results of this investigation [7] reported between $400 \mathrm{mg}$ sodium/day and $1500 \mathrm{mg} /$ day (for teenagers from 15 years old and under 19 years old).

Furthermore, the 2015-2020 US Dietary Guidelines recommend that Americans consume $<2300 \mathrm{mg}$ of sodium per day and suggest further limiting sodium intake for younger subgroups [9]. The Institute of Medicine indicates that the tolerable upper intake level for sodium is $1900 \mathrm{mg} /$ day for children from 4 to 8 years old; $2200 \mathrm{mg} /$ day for children aged 9 to 13 years old and $2300 \mathrm{mg} /$ day for those aged 14 years and older [6].

This is a pioneer study in Costa Rica for sodium intake estimation and in determining the groups and types of foods that most contribute to this intake in children and teenagers. These results can help to understand in a better way the national problem in these populations in order to define interventions that seek to effectively reduce excessive consumption of salt/sodium in children and teenagers, considering different food groups and age groups [10]. In addition, this research examined daily calorie intake, sodium intake and sodium density (milligrams of sodium per $1000 \mathrm{kcal}$ ), evidence that can be helpful for policymakers 
and food industry by distinguishing or recognizing differences in sodium intake and sources among the young Costa Rican population according to subgroups of age, sex, socioeconomic status and nutritional status due to excess body weight.

\section{Methodological Framework}

A cross-sectional study was performed in a population of 2685 students from 24 elementary-middle schools and 40 high schools (private and public) of Costa Rica with a daytime schedule in 2016 . The proportion estimation formula was used with a $95 \%$ confidence interval and a standard error of $3 \%$. In each educational center a total of 40 children and adolescents were randomly selected using age ( 7 to 18 years) as the only inclusion criteria. Exclusion criteria included: incomplete participant information, inability to read and write, history of eating disorders, celiac disease or diabetes mellitus and alcohol or illicit drug dependence.

Sociodemographic data: sex, age and socioeconomic status of the students were determined according to the methodology described by Madrigal [11], for which an index was built according to the possession of some specific material goods at home.

Anthropometric data: weight was determined twice to all students using a Tanita scale model SC-331S (without column) and height was determined using a freely positioning stadiometer with a wall separator, SECA brand, model 217. A third measurement was performed if a difference greater than $0.5 \mathrm{~cm}$ was noticed between the average of the two measurements. Body mass composition and BMI were assessed using this Tanita. Body weight was measured with the subject barefoot and in light clothing (shorts and T-shirt). Height was measured in an upright position, back to the measuring rod with the internal malleoli together and heels, buttocks, shoulders and posterior region of the head in contact with the apparatus. The BMI $\left(\mathrm{kg} / \mathrm{m}^{2}\right)$ was estimated for each participant. Overweight and obesity were defined according to WHO Child Growth Standards Length/height-for-age, weight-for-age, weight-for-length, weight-for-height and body mass index-for age and sex (BMI $\geq 85$ percentile and $<95$ percentile for overweight and BMI $\geq 95$ percentile for obesity) [12] [13]. Comparative analysis in groups was conducted based on standardized values with BMI categories (with or without body excess).

Food data: a food frequency survey was designed and applied to study the food and beverage intake habits of the participants. The questionnaire was adapted from one previously validated [14] and used survey by this research team and applied individually with the supervision of two nutritionists. Demographic and socioeconomic variables were also explored in this questionnaire. Children who attended first, second and third year of school were interviewed.

This survey comprehended foods and dishes commonly consumed in Costa Rica and an open section for students to include other foods not present in the list. Students were encouraged to include and register the intake frequency of 
any other food not found in this survey. The result was a list of 120 foods including homemade and industrial products that are part of the Costa Rican diet and the global habits of children and adolescents [15] [16]. For example, the intake of carbonated drinks, fast food, and hidden and added sodium dietary food sources, visible fat and fried foods were investigated.

Estimation of the portion size of the food was established through the photographic manual of portions of foods and common preparations of Costa Rica and the weight book of homemade measurements and portions of common foods and preparations of Costa Rica, taking as reference the smallest portion of each food registered by participants in the questionnaire to avoid overestimation [17] [18].

Estimation of the sodium content of foods was carried out by four different methods, with the aim of providing the best approximation of the consumption of this nutrient in subjects from an early age. Method 1 or direct method, consisted of determining the amount of sodium in food commonly prepared in Costa Rica through laboratory analysis carried out by Montero-Campos and collaborators [19] [20]. The food analyzed by method 1 were the "casado" (typical Costa Rican dish of rice and beans with chicken, beef or pork), "gallo pinto" (typical dish that combines rice and beans), sweet bread with filling, "empanada", croissants, french fries, doraditas (fried corn snack), beef tacos, hamburger, ham and cheese pizza, baguette bread with cheese, fried chicken, Cantonese rice, rice with chicken, "corn tortilla" with cheese, "chorreadas" (sweet corn tortilla), stuffed salad bread, hot dogs, mixed nachos and meat pot. These foods were assigned with the lower limit of sodium content according to what was reported by Montero-Campos and collaborators. The energy contribution of the food was estimated according to the calories reported in the Institute of Nutrition of Central America and Panama (INCAP) Food Composition Table for Central America [21], the commercial nutritional labeling of each processed or packaged product and the USDA Food Composition Databases of the Department of Agriculture of United States of America [22], depending on the availability of data.

Method 2 or indirect method, consisted of determining the amount of sodium present in food using the INCAP Food Composition Table for Central America [21]. This Method 2 was applied to those foods that are not part of the Montero-Campos and collaborators.

Subsequently, those foods whose sodium content was not determined in any of the methods mentioned before, the amount of sodium was calculated using method 3, which consisted of taking the information from the commercial nutritional labeling. For each of the foods, its sodium content was estimated at 100 grams and according to the declared portions of the label and in the USDA Food Composition Databases of the Department of Agriculture of the United States [22].

The fourth method consisted of calculating the sodium and calorie content of the recipe with the different ingredients (for example: plantain with cheese, cin- 
namon, margarine and sugar). The sodium content in each of the food ingredients was estimated, through standardized recipes established in the book of weight of homemade measures and portions of common foods and preparations in Costa Rica [18]. Finally, the sodium and calorie content of these recipes was determined, based on what was reported in INCAP Food Composition Table for Central America [21] or the USDA Food Composition Databases of the Department of Agriculture of the United States [22].

The formula used to estimate sodium was:

[(Serving size in grams $) \times(100$ grams $) /($ Sodium content in 100 grams $)]$

The formula used to estimate calories was:

[(Serving size in grams $) \times(100$ grams $) /($ Calorie content in 100 grams $)]$

To calculate the daily intake in grams, we multiplied the estimated number of servings by the frequency factor. The frequency factors used were: 0 (Never), 0.036 (1 day a month), 0.142 ( 1 day a week); 0.285 ( 2 days a week); 0.428 (3 days a week); 0.571 (4 days a week); 0.714 (5 days a week); 0.857 (6 days a week) and 1 (7 days a week).

With the purpose of estimating the amount of common salt that students add to meals or foods (not for cooking), the average weight of common salt used for this purpose was calculated. To do this, each student was asked whether adds salt to the plate of an entire meal served or directly to specific foods. In Costa Rica it is common to eat fruits (mango, pineapple), sour cream, and avocado, among others, with added salt. In addition, the frequency of "pinches" of salt used was asked, in case the student answered that they did add salt. It should be noted that in Costa Rica, a "pinch" is the amount of salt that the person can trap between the thumb and index fingers. About 200 pinches of refined salt from a sample of students ( $50 \%$ of each sex) were weighed on an electronic scale (Kern brand) weighing 620 grams maximum weight and $0.01 \mathrm{~g}$ minimum weight: 40 from 7 to 9 years old, 80 from 10 to 12 years old, 50 from 13 to 15 years old and 30 from 16 to 18 years old. Based on these weights, the average weight of a pinch was calculated, which turned out to be 0.359 grams of salt or $142 \mathrm{mg}$ of sodium.

Also, each student was asked if they added sauces: soy, Salsa Lizano ${ }^{\varpi}$, pink (tomato and mayonnaise) and dressings to the served food such as Chinese food, French fries, bread, among others and the frequency. The amounts of sauces and dressings were not weighed; each portion was estimated according to the theoretical weight reported in the food composition databases consulted [21] and sodium estimated.

Statistical analysis: The variables of interest are described using the average and standard deviation according to age groups, sex (girls and boys), socioeconomic and nutritional status (without and with excess body weight). Differences between groups are explained using parametric or non-parametric tests depending on the normal distribution. Data defined by more than two categories were tested using ANOVA or Kruskal-Wallis test depending on the distribution. 


\section{Results}

The different foods and beverages examined in this study were included and classified into 25 groups, which are detailed in Table 1 . The 25 groups are varied with the purpose to estimate sodium intake in children and adolescents and determine the groups and types of foods that contribute most to sodium intake in these populations.

Table 1. List of foods, beverages and preparations whose frequency were investigated by the national survey in the Costa Rican children and adolescents aged 7 to 18 years.

Food groups Foods, beverages and preparations

1) Meats with visible or fried fat, (fried chicken, mainly) alone or in "casado" (dish of rice with Chicken, pork rinds, beef or pork ribs with bacon beans) *

2) Soy or spices (Salsa Lizano ${ }^{\circ}$ ) sauces

3) Fried prepared pastries and sandwiches

4) Fast foods

5) Tomato (ketchup) or pink sauce

6) Cereals and/or "gallo pinto"

7) Salted seeds

8) Processed meats/sausages

9) Cookies and crackers?

10) Snacks in small packages

11) Popcorn

12) Ripe or creamy cheeses

13) Milk and derivatives

14) White meats (not fried)

15) Dressings

16) Soups

17) Red meats and eggs (alone or in "casado" *)

18) Legumes

19) Starchy vegetables and tropical roots

20) Sweets and creamy ice cream

21) Non-starchy vegetables

22) Fruits

23) Sport drinks

24) Energy drinks

25) Others drinks
Soy and spices sauces (Salsa Lizano ${ }^{\circ}$ ) among others

Puff pastry, "empanadas", "churros", among others

Ham and cheese pizza, hot dog, beef taco, fried chicken, Cantonese rice, rice with chicken, cheese tortilla, "chorreadas", hamburger, mixed nachos, Chinese food, among others

Tomato or pink sauce (tomato sauce and mayonnaise mix)

Non-whole and whole grains: rice, barley, oats, breakfast cereals, "tortilla", and breads, stuffed salad bread, baguette bread with cheese, "gallo pinto", among others

Almonds, nuts, among others with added salt

Sausage, mortadella

Any cookie (stuffed or not)

Roasted potatoes, fried plantains, among others

Popcorn of any kind, with salt

Yellow cheese of any kind; ripe (not white or fresh), for melting or frying

Skimmed or semi-skimmed milk, yogurt and fresh white cheese (not ripe or creamy); whole milk and flavored milk

Chicken, fish, tuna, "scrambled" (not fried)

Mayonnaise, cream cheese, mustard, among others

Ready-made soups (instant) ready to heat and consume

No visible fat: beef, pork, chicken egg

Beans of any color, lentils, chickpeas, peas

Potato, cassava, sweet potato, cocoyam, ñampí, among others

Sweets, chocolates, creamy ice cream of any kind

Carrot, cabbage, tomato, tender squash, lettuce, cucumber, among others

Papaya, melon, watermelon, banana, guava, soursop, orange, tangerine, among others

Sport drinks

Energy drinks

Soda cola, soda citrus flavor, other carbonated drinks, concentrated juices powdered or packed with added sugar, flavored water, beer, white or red wine or sparkling wine, whiskey, vodka, rum, among others

* Traditional Costa Rica's meal. 
The average daily sodium intake of children and adolescents $(\mathrm{n}=2685)$ from 7 to 18 years old was $3214 \mathrm{mg}$, excluding the addition of common "pinches" or discretionary salt to the plate served (at the table) or food. Around $97 \%$ of the students had sodium intakes $>2300 \mathrm{mg}$ per day. Sodium intake differed by age subgroup ( $\mathrm{p}<0.001)$, sex $(\mathrm{p}<0.001)$ and nutritional status due to excess body weight $(\mathrm{p}<0.001)$ (Table 2$)$. No differences were observed in the daily sodium intake average by socioeconomic status (Table 2 ).

The average daily energy intake of the study population was $1888 \mathrm{kcal}$ and differed by subgroup of age ( $\mathrm{p}<0.001)$, sex ( $<<0.001)$, socioeconomic status ( $\mathrm{p}$ $=0.013)$ and nutritional status due to excess body weight $(\mathrm{p}<0.001)$ (Table 2$)$. The sodium density average was $1698 \mathrm{mg}$ of sodium/1000kcal with significant differences by subgroups of age ( $p<0.001)$, sex $(\mathrm{p}<0.001)$, socioeconomic status $(\mathrm{p}=0.021)$ and nutritional status due to excess body weight $(\mathrm{p}<0.001)$ (Table 2).

Table 2. Daily intake of sodium and energy, sodium density of the diet ${ }^{*}$ by age group, sex, socioeconomic status, and nutritional status: National survey, Costa Rican children and adolescents aged 7 to 18 years.

\begin{tabular}{|c|c|c|c|c|}
\hline Variable & $\mathbf{n}$ & $\begin{array}{c}\text { Mean sodium consumed } \\
\text { (mg/d } \pm \text { standard deviation) }\end{array}$ & $\begin{array}{c}\text { Mean energy consumed } \\
\text { (Kcal/d } \pm \text { standard deviation) }\end{array}$ & $\begin{array}{c}\text { Sodium density } \\
(\mathrm{mg} / 1000 \mathrm{Kcal} \pm \text { standard deviation) }\end{array}$ \\
\hline Total & 2685 & $3214 \pm 809$ & $1888 \pm 402$ & $1698 \pm 168$ \\
\hline Age group (y) & 2685 & & & \\
\hline $7-9$ & 361 & $2717 \pm 519$ & $1698 \pm 307$ & $1606 \pm 160$ \\
\hline $10-12$ & 1103 & $3334 \pm 790$ & $1915 \pm 399$ & $1738 \pm 151$ \\
\hline $13-15$ & 877 & $3232 \pm 835$ & $1908 \pm 397$ & $1687 \pm 164$ \\
\hline $16-18$ & 344 & $3305 \pm 860$ & $1955 \pm 449$ & $1693 \pm 190$ \\
\hline$p$ value & & $<0.001$ & $<0.001$ & $<0.001$ \\
\hline Sex & 2685 & & & \\
\hline Male & 1265 & $3514 \pm 864$ & $2029 \pm 404$ & $1725 \pm 165$ \\
\hline Female & 1420 & $2947 \pm 649$ & $1763 \pm 355$ & $1674 \pm 167$ \\
\hline$p$ value & & $<0.001$ & $<0.001$ & $<0.001$ \\
\hline Socioeconomic status $\left(^{* *}\right)$ & 2685 & & & \\
\hline Low & 754 & $3168 \pm 760$ & $1849 \pm 376$ & $1710 \pm 164$ \\
\hline Medium & 1506 & $3223 \pm 830$ & $1899 \pm 412$ & $1693 \pm 170$ \\
\hline High & 425 & $3266 \pm 818$ & $1923 \pm 405$ & $1694 \pm 166$ \\
\hline$p$ value & & 0.199 & 0.013 & 0.021 \\
\hline Overweight/obese & 2685 & & & \\
\hline Yes & 695 & $3917 \pm 893$ & $2264 \pm 412$ & $1726 \pm 172$ \\
\hline No & 1990 & $2968 \pm 610$ & $1757 \pm 303$ & $1688 \pm 165$ \\
\hline$p$ value & & $<0.001$ & $<0.001$ & $<0.001$ \\
\hline
\end{tabular}

$\left.{ }^{*}\right)$ Without considering the addition of salt to the served plate or food. ${ }^{* *}$ ) Low, medium and high socioeconomic status was defined with an index built according to the possession of some specific material goods at home. y: years; $n$ : number of participants; d: day; $\mathrm{p}$ value significantly if lower than 0.05 . 
The average of "pinches" of common salt added to the served plate (at the table) or food was $445 \mathrm{mg}$ of sodium (1.1 grams of salt) with significant differences by subgroups of age, with the lowest mean sodium consumed in the 10 to 12-year-old subgroup ( $408 \mathrm{mg} / \mathrm{d}$ ) and the highest in the 16 to 18-year-old group $(554 \mathrm{mg} / \mathrm{d})$; sex ( $481 \mathrm{mg} / \mathrm{d}$ in girls versus $402 \mathrm{mg} / \mathrm{d}$ in boys) and socioeconomic status (mean sodium consumed is observed in ascending order as socioeconomic status increases) $(\mathrm{p}<0.001)$. No differences were observed in the average of added pinches of salt by nutritional status (excess body weight) (Table 3). Including this amount of sodium added to the served plate (at the table) or food, the average sodium intake for children and adolescents from 7 to 18 years old increased to $3434 \mathrm{mg}$, with significant differences by subgroups of age, with the lowest mean sodium consumed in the 7 to 9 -year-old subgroup $(2833 \mathrm{mg} / \mathrm{d})$ and the highest in the 16 to 18 -year-old group $(3603 \mathrm{mg} / \mathrm{d})$; sex $(3549 \mathrm{mg} / \mathrm{d}$ in girls versus $2833 \mathrm{mg} / \mathrm{d}$ in boys) and socioeconomic (mean sodium consumed is observed in ascending order as socioeconomic status increases) and nutritional status due to excess body weight $(4126 \mathrm{mg} / \mathrm{d}$ in the subjects with overweight versus $2833 \mathrm{mg} / \mathrm{d}$ in the participants without overweight) $(\mathrm{p}<0.001)$ (Table 4) and in general, the sodium density average increased to $1821 \mathrm{mg}$ sodium/1000kcal, keeping significant differences by subgroups of age, with the lowest mean sodium consumed in the 7 to 9 -year-old subgroup $(1678 \mathrm{mg} / \mathrm{d})$ and the highest in the 16 to 18 -year-old group $(1853 \mathrm{mg} / \mathrm{d})(\mathrm{p}<0.001)$. No significant differences were observed in the sodium density average of the diet, considering the addition of salt by sex, socioeconomic and nutritional status (excess body weight) (Table 4).

Regarding the addition of common salt to the served plate (at the table) or to the foods, almost half of the total of the participating students $(n=1326,49.4 \%)$ reported adding at least one "pinch" of salt to their plate or fruits (mango, pineapple), sour cream, avocado, among others. Near $44.3 \%(\mathrm{n}=587)$ of these 1326 students reported that on a frequency of 1 to 2 days a week it is common to add 1 "pinch" of salt to the served plate or food and 34.2\% $(\mathrm{n}=453)$ reported that it is common to add from two to four "pinches" of salt on the same frequency ( 1 to 2 days a week); $6 \%(n=80)$ said that on a frequency of 3 to 4 days a week they usually add 1 "pinch" of salt to the plate served or food, and $15.5 \%$ (n $=206$ ) reported that they usually add two to four "pinches" of salt at the same frequency ( 3 to 4 days a week) (data not shown in table).

The 10 main groups of food that contribute to sodium intake in children and adolescents were: 1) Meats with visible or fried fat, alone or in "casado" (mainly with fried chicken); 2) Soy or spices sauces (Salsa Lizano ${ }^{\circledR}$ ); 3) Fried prepared pastries and sandwiches; 4) Fast foods; 5) Tomato or pink sauce; 6) Cereals and/or "gallo pinto"; 7) Salted seeds; 8) Processed meats/sausages; 9) Crackers, cookies and 10) Snacks in small packages (Table 5). These 10 food groups contributed with near $63 \%$ of the sodium consumed by children and adolescents from 7 to 18 years old and the remaining 37\% came from the other 15 food groups. 
In general, the first five food groups previously listed (meats with visible or fried fat, alone or in "casado"-fried chicken, mainly-soy or spices (Lizano") sauces; fried prepared pastries and sandwiches; fast food, and tomato or pink sauces-tomato sauce and mayonnaise mix) were the ones that contributed to most of sodium intake (Table 5). Despite the similarities in the contributions of the main food categories, the total contribution of sodium intake differed for some food categories in the population subgroups. For example, among high school adolescents from 13 - 18 years old (from 9.12 to 13.08); males (11.77); of high socioeconomic status (9.85) and those who are not overweight (11.56), the soy or spices (Salsa Lizano ${ }^{\circledR}$ ) sauces are the first highest contributor of sodium, but the second highest in all other age subgroups examined (9.69) and third highest among those with excess weight (9.03).

Table 3. Mean ( \pm standard deviation) daily sodium intake from the amount of salt added by age group: National survey, 1326 Costa Rican children and adolescents aged from 7 to 18 years, who used to add salt in serving meals and food.

\begin{tabular}{|c|c|c|c|}
\hline Variable & $\begin{array}{c}\mathrm{n} \\
(1326)\end{array}$ & $\begin{array}{l}\text { Proportion (\%) of the participating } \\
\text { population ( } \mathrm{n} 2685)\end{array}$ & $\begin{array}{c}\text { Sodium consumed } \\
\text { (mean } \mathrm{mg} / \mathrm{d} \pm \mathrm{SD}) \text { from added salt }\end{array}$ \\
\hline Total & 1326 & 49 & $445 \pm 303$ \\
\hline Age group (y) & 1326 & 49 & \\
\hline $7-9$ & 97 & 27 & $430 \pm 253$ \\
\hline $10-12$ & 581 & 52 & $408 \pm 253$ \\
\hline $13-15$ & 463 & 53 & $451 \pm 301$ \\
\hline $16-18$ & 185 & 54 & $554 \pm 376$ \\
\hline$p$ value & & & $<0.001$ \\
\hline Sex & 1326 & 49 & \\
\hline Male & 615 & 49 & $402 \pm 255$ \\
\hline Female & 711 & 50 & $481 \pm 325$ \\
\hline$p$ value & & & $<0.001$ \\
\hline Socioeconomic status & 1326 & 49 & \\
\hline Low & 321 & 43 & $389 \pm 264$ \\
\hline Medium & 787 & 52 & $461 \pm 298$ \\
\hline High & 218 & 51 & $470 \pm 329$ \\
\hline$p$ value & & & $<0.001$ \\
\hline Overweight/obese & 1326 & 49 & \\
\hline Yes & 342 & 49 & $425 \pm 271$ \\
\hline No & 984 & 49 & $452 \pm 305$ \\
\hline$p$ value & & & $<0.161$ \\
\hline
\end{tabular}

y: years; $n$ : number of participants; $d$ : day; mg: milligrams; $p$ value significant if $\leq 0.05$. 
Table 4. Comparison of daily sodium intake and sodium density, without and with the addition of salt to the served plate and food by age group, sex, socioeconomic and nutritional status: National survey, Costa Rican children and adolescents aged 7 to 18 years.

\begin{tabular}{|c|c|c|c|c|c|}
\hline \multirow{2}{*}{ Variable } & \multirow{2}{*}{$\mathbf{n}$} & \multicolumn{2}{|c|}{$\begin{array}{l}\text { Mean sodium consumed } \\
\qquad(\mathrm{mg} / \mathrm{d} \pm \mathrm{SD})\end{array}$} & \multicolumn{2}{|c|}{$\begin{array}{c}\text { Sodium density } \\
(\mathrm{mg} / 1000 \mathrm{Kcal} \pm \mathrm{SD})\end{array}$} \\
\hline & & $\begin{array}{l}\text { Without adding salt to } \\
\text { the served dish and food }\end{array}$ & $\begin{array}{l}\text { With addition of salt to } \\
\text { the served dish and food }\end{array}$ & $\begin{array}{l}\text { Without adding salt to } \\
\text { the served dish and food }\end{array}$ & $\begin{array}{l}\text { With addition of salt to } \\
\text { the served dish and food }\end{array}$ \\
\hline Total & 2685 & $3214 \pm 809$ & $3434 \pm 845$ & $1698 \pm 168$ & $1821 \pm 241$ \\
\hline Age group (y) & 2685 & & & & \\
\hline $7-9$ & 361 & $2717 \pm 519$ & $2833 \pm 556$ & $1606 \pm 160$ & $1678 \pm 221$ \\
\hline $10-12$ & 1103 & $3334 \pm 790$ & $3549 \pm 807$ & $1738 \pm 151$ & $1859 \pm 220$ \\
\hline $13-15$ & 877 & $3232 \pm 835$ & $3470 \pm 851$ & $1687 \pm 164$ & $1820 \pm 234$ \\
\hline $16-18$ & 344 & $3305 \pm 860$ & $3603 \pm 933$ & $1693 \pm 190$ & $1853 \pm 286$ \\
\hline$p$ value & & $<0.001$ & $<0.001$ & $<0.001$ & $<0.001$ \\
\hline Sex & 2685 & & & & \\
\hline Male & 1265 & $2717 \pm 519$ & $2833 \pm 556$ & $1606 \pm 160$ & $1678 \pm 221$ \\
\hline Female & 1420 & $3334 \pm 790$ & $3549 \pm 807$ & $1738 \pm 151$ & $1859 \pm 220$ \\
\hline$p$ value & & $<0.001$ & $<0.001$ & $<0.001$ & 0.434 \\
\hline Socioeconomic status & 2685 & & & & \\
\hline Low & 754 & $3168 \pm 760$ & $3334 \pm 784$ & $1710 \pm 164$ & $1805 \pm 224$ \\
\hline Medium & 1506 & $3223 \pm 830$ & $3465 \pm 874$ & $1693 \pm 170$ & $1827 \pm 252$ \\
\hline High & 425 & $3266 \pm 818$ & $3507 \pm 835$ & $1694 \pm 166$ & $1828 \pm 232$ \\
\hline$p$ value & & 0.199 & $<0.001$ & 0.021 & 0.342 \\
\hline Overweight/obese & 2685 & & & & \\
\hline Yes & 695 & $3917 \pm 893$ & $4126 \pm 939$ & $1725.5001 \pm 171.57359$ & $1821 \pm 219$ \\
\hline No & 1990 & $2968 \pm 610$ & $3192 \pm 656$ & $1688.3086 \pm 165.09752$ & $1821 \pm 249$ \\
\hline$p$ value & & $<0.001$ & $<0.001$ & $<0.001$ & 0.958 \\
\hline
\end{tabular}

y: years; $n$ : number of participants; d: day; mg: milligrams; $p$ value significant if lower than 0.05 .

Table 5. Ranked population proportions of daily sodium consumed ${ }^{a}$ by food category, age group, sex, socioeconomic and nutritional status: National survey, Costa Rican children and adolescents aged 7 to 18 years.

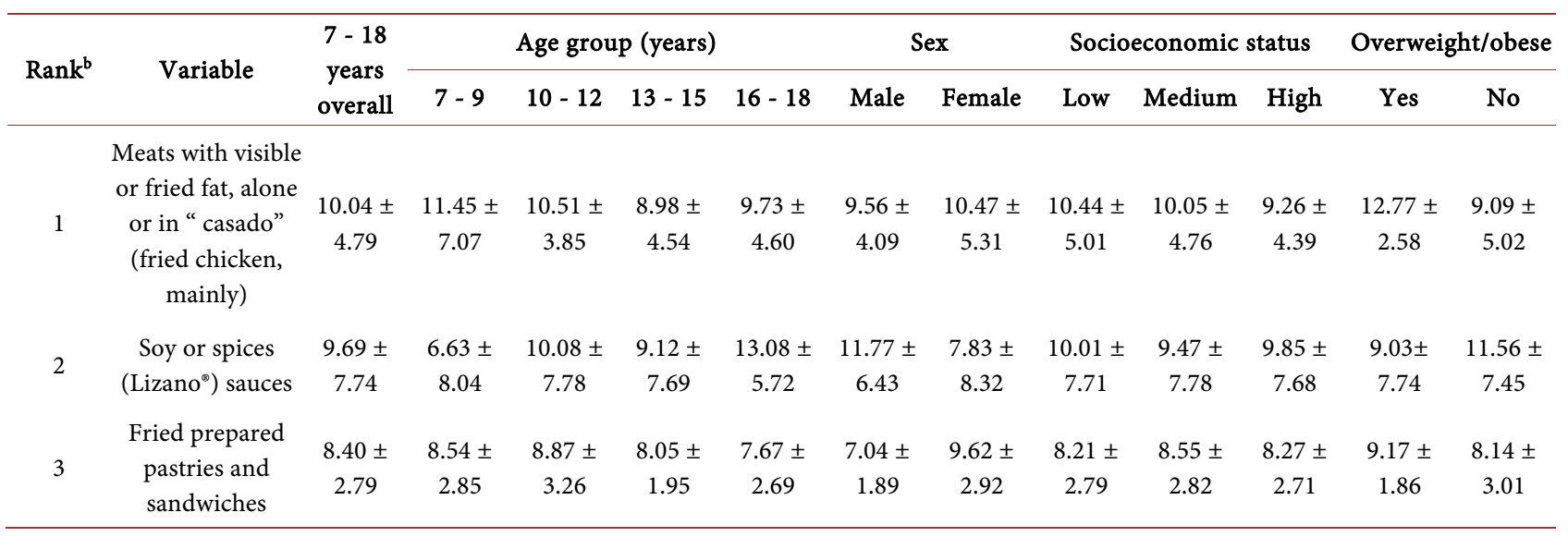




\section{Continued}

\begin{tabular}{|c|c|c|c|c|c|c|c|c|c|c|c|c|c|}
\hline 4 & Fast foods & $\begin{array}{c}6.86 \pm \\
2.93\end{array}$ & $\begin{array}{c}5.89 \pm \\
3.46\end{array}$ & $\begin{array}{c}7.45 \pm \\
2.87\end{array}$ & $\begin{array}{c}6.53 \pm \\
2.54\end{array}$ & $\begin{array}{c}6.86 \pm \\
3.09\end{array}$ & $\begin{array}{c}6.95 \pm \\
2.94\end{array}$ & $\begin{array}{c}6.79 \pm \\
2.93\end{array}$ & $\begin{array}{c}6.94 \pm \\
2.99\end{array}$ & $\begin{array}{c}6.77 \pm \\
2.94\end{array}$ & $\begin{array}{c}7.05 \pm \\
2.81\end{array}$ & $\begin{array}{c}5.99 \pm \\
2.35\end{array}$ & $\begin{array}{c}7.17 \pm \\
3.06\end{array}$ \\
\hline 5 & $\begin{array}{l}\text { Tomato or pink } \\
\text { sauces (tomato } \\
\text { sauce and } \\
\text { mayonnaise mix) }\end{array}$ & $\begin{array}{c}6.62 \pm \\
1.73\end{array}$ & $\begin{array}{c}7.72 \pm \\
1.54\end{array}$ & $\begin{array}{c}6.43 \pm \\
1.73\end{array}$ & $\begin{array}{c}6.70 \pm \\
1.77\end{array}$ & $\begin{array}{c}6.48 \pm \\
1.67\end{array}$ & $\begin{array}{c}6.41 \pm \\
1.78\end{array}$ & $\begin{array}{c}6.81 \pm \\
1.66\end{array}$ & $\begin{array}{c}6.60 \pm \\
1.64\end{array}$ & $\begin{array}{c}6.64 \pm \\
1.78\end{array}$ & $\begin{array}{c}6.63 \pm \\
1.76\end{array}$ & $\begin{array}{c}6.06 \pm \\
1.62\end{array}$ & $\begin{array}{c}6.82 \pm \\
1.72\end{array}$ \\
\hline 6 & $\begin{array}{l}\text { Cereals and/or } \\
\text { "gallo pinto" }\end{array}$ & $\begin{array}{c}6.12 \pm \\
1.23\end{array}$ & $\begin{array}{c}6.65 \pm \\
1.04\end{array}$ & $\begin{array}{c}5.93 \pm \\
1.23\end{array}$ & $\begin{array}{c}6.20 \pm \\
1.27\end{array}$ & $\begin{array}{c}5.98 \pm \\
1.17\end{array}$ & $\begin{array}{c}5.91 \pm \\
1.28\end{array}$ & $\begin{array}{c}6.31 \pm \\
1.15\end{array}$ & $\begin{array}{c}6.10 \pm \\
1.13\end{array}$ & $\begin{array}{c}6.14 \pm \\
1.28\end{array}$ & $\begin{array}{c}6.13 \pm \\
1.26\end{array}$ & $\begin{array}{c}5.56 \pm \\
1.12\end{array}$ & $\begin{array}{c}6.32 \pm \\
1.21\end{array}$ \\
\hline 7 & Salted seeds & $\begin{array}{c}5.18 \pm \\
3.61\end{array}$ & $\begin{array}{c}6.96 \pm \\
4.83\end{array}$ & $\begin{array}{c}4.92 \pm \\
2.56\end{array}$ & $\begin{array}{c}4.74 \pm \\
3.89\end{array}$ & $\begin{array}{c}5.29 \pm \\
3.69\end{array}$ & $\begin{array}{c}4.26 \pm \\
2.86\end{array}$ & $\begin{array}{c}6.01 \pm \\
3.99\end{array}$ & $\begin{array}{c}5.67 \pm \\
3.68\end{array}$ & $\begin{array}{c}5.07 \pm \\
3.63\end{array}$ & $\begin{array}{c}4.75 \pm \\
3.32\end{array}$ & $\begin{array}{c}3.88 \pm \\
3.12\end{array}$ & $\begin{array}{c}5.64 \pm \\
3.66\end{array}$ \\
\hline 8 & $\begin{array}{c}\text { Processed } \\
\text { meats/sausages }\end{array}$ & $\begin{array}{c}4.82 \pm \\
1.62\end{array}$ & $\begin{array}{c}5.92 \pm \\
2.22\end{array}$ & $\begin{array}{c}4.76 \pm \\
1.14\end{array}$ & $\begin{array}{c}4.51 \pm \\
1.68\end{array}$ & $\begin{array}{c}4.63 \pm \\
1.54\end{array}$ & $\begin{array}{c}4.51 \pm \\
1.35\end{array}$ & $\begin{array}{c}5.10 \pm \\
1.78\end{array}$ & $\begin{array}{c}4.98 \pm \\
1.65\end{array}$ & $\begin{array}{c}4.82 \pm \\
1.60\end{array}$ & $\begin{array}{c}4.52 \pm \\
1.56\end{array}$ & $\begin{array}{c}5.12 \pm \\
1.03\end{array}$ & $\begin{array}{c}4.71 \pm \\
1.77\end{array}$ \\
\hline 9 & Salty cookies & $\begin{array}{c}4.68 \pm \\
2.11\end{array}$ & $\begin{array}{c}3.83 \pm \\
2.66\end{array}$ & $\begin{array}{c}4.63 \pm \\
1.71\end{array}$ & $\begin{array}{c}4.92 \pm \\
2.36\end{array}$ & $\begin{array}{c}5.10 \pm \\
1.69\end{array}$ & $\begin{array}{c}5.10 \pm \\
1.71\end{array}$ & $\begin{array}{c}4.30 \pm \\
2.35\end{array}$ & $\begin{array}{c}4.53 \pm \\
2.11\end{array}$ & $\begin{array}{c}4.73 \pm \\
2.11\end{array}$ & $\begin{array}{c}4.77 \pm \\
2.16\end{array}$ & $\begin{array}{c}5.08 \pm \\
1.03\end{array}$ & $\begin{array}{c}4.54 \pm \\
2.37\end{array}$ \\
\hline 10 & $\begin{array}{l}\text { Snacks in small } \\
\text { packages }\end{array}$ & $\begin{array}{c}4.55 \\
\pm 0.96\end{array}$ & $\begin{array}{c}5.29 \\
\pm 0.94\end{array}$ & $\begin{array}{c}4.37 \\
\pm 0.90\end{array}$ & $\begin{array}{c}4.53 \\
\pm 0.94\end{array}$ & $\begin{array}{c}4.43 \\
\pm 0.90\end{array}$ & $\begin{array}{c}4.16 \\
\pm 0.89\end{array}$ & $\begin{array}{c}4.90 \\
\pm 0.89\end{array}$ & $\begin{array}{c}4.60 \\
\pm 0.93\end{array}$ & $\begin{array}{c}4.55 \\
\pm 0.99\end{array}$ & $\begin{array}{c}4.83 \\
\pm 0.94\end{array}$ & $\begin{array}{c}3.71 \\
\pm 0.75\end{array}$ & $\begin{array}{c}4.85 \\
\pm 0.85\end{array}$ \\
\hline 11 & Popcorn & $\begin{array}{c}4.30 \pm \\
2.38\end{array}$ & $\begin{array}{c}2.66 \pm \\
2.64\end{array}$ & $\begin{array}{c}4.20 \pm \\
2.11\end{array}$ & $\begin{array}{c}5.03 \pm \\
2.31\end{array}$ & $\begin{array}{c}4.51 \pm \\
2.18\end{array}$ & $\begin{array}{c}4.07 \pm \\
1.97\end{array}$ & $\begin{array}{c}4.52 \pm \\
2.67\end{array}$ & $\begin{array}{c}4.04 \pm \\
2.47\end{array}$ & $\begin{array}{c}4.33 \pm \\
2.36\end{array}$ & $\begin{array}{c}4.72 \pm \\
2.23\end{array}$ & $\begin{array}{c}4.08 \pm \\
1.94\end{array}$ & $\begin{array}{c}4.38 \pm \\
2.50\end{array}$ \\
\hline 12 & $\begin{array}{l}\text { Ripe or creamy } \\
\text { cheeses }\end{array}$ & $\begin{array}{c}3.43 \pm \\
1.32\end{array}$ & $\begin{array}{c}3.42 \\
1.92 \pm\end{array}$ & $\begin{array}{c}3.58 \pm \\
1.33\end{array}$ & $\begin{array}{c}3.32 \\
\pm 0.82\end{array}$ & $\begin{array}{c}3.24 \pm \\
1.47\end{array}$ & $\begin{array}{c}3.73 \pm \\
1.20\end{array}$ & $\begin{array}{c}3.15 \pm \\
1.36\end{array}$ & $\begin{array}{c}3.50 \pm \\
1.41\end{array}$ & $\begin{array}{c}3.39 \pm \\
1.31\end{array}$ & $\begin{array}{c}3.44 \pm \\
1.16\end{array}$ & $\begin{array}{c}2.92 \pm \\
1.21\end{array}$ & $\begin{array}{c}3.60 \pm \\
1.31\end{array}$ \\
\hline 13 & $\begin{array}{l}\text { Milk and } \\
\text { derivatives }\end{array}$ & $\begin{array}{c}3.20 \pm \\
2.91\end{array}$ & $\begin{array}{c}3.95 \pm \\
1.99\end{array}$ & $\begin{array}{c}2.72 \pm \\
2.92\end{array}$ & $\begin{array}{c}3.43 \pm \\
2.92\end{array}$ & $\begin{array}{c}3.37 \pm \\
3.32\end{array}$ & $\begin{array}{c}3.46 \pm \\
3.52\end{array}$ & $\begin{array}{c}2.97 \pm \\
2.19\end{array}$ & $\begin{array}{c}2.74 \pm \\
2.84\end{array}$ & $\begin{array}{c}3.38 \pm \\
2.95\end{array}$ & $\begin{array}{c}3.38 \pm \\
2.78\end{array}$ & $\begin{array}{c}3.97 \pm \\
4.49\end{array}$ & $\begin{array}{c}2.93 \pm \\
2.02\end{array}$ \\
\hline 14 & White meats & $\begin{array}{c}2.69 \pm \\
2.02\end{array}$ & $\begin{array}{c}2.91 \pm \\
1.81\end{array}$ & $\begin{array}{c}2.57 \pm \\
2.22\end{array}$ & $\begin{array}{c}2.91 \pm \\
1.93\end{array}$ & $\begin{array}{c}2.30 \pm \\
1.64\end{array}$ & $\begin{array}{c}3.71 \pm \\
1.92\end{array}$ & $\begin{array}{c}1.79 \pm \\
1.64\end{array}$ & $\begin{array}{c}2.80 \pm \\
2.03\end{array}$ & $\begin{array}{c}2.64 \pm \\
2.00\end{array}$ & $\begin{array}{c}2.68 \pm \\
2.05\end{array}$ & $\begin{array}{c}1.90 \pm \\
2.70\end{array}$ & $\begin{array}{c}2.63 \pm \\
2.05\end{array}$ \\
\hline 15 & Dressings & $\begin{array}{c}2.51 \pm \\
1.66\end{array}$ & $\begin{array}{c}3.43 \pm \\
1.93\end{array}$ & $\begin{array}{c}2.14 \pm \\
1.50\end{array}$ & $\begin{array}{c}2.64 \pm \\
1.62\end{array}$ & $\begin{array}{c}2.38 \pm \\
1.49\end{array}$ & $\begin{array}{c}2.71 \pm \\
1.55\end{array}$ & $\begin{array}{c}2.32 \pm \\
1.72\end{array}$ & $\begin{array}{c}2.10 \pm \\
1.58\end{array}$ & $\begin{array}{c}2.63 \pm \\
1.68\end{array}$ & $\begin{array}{c}2.78 \pm \\
1.56\end{array}$ & $\begin{array}{c}2.02 \pm \\
1.35\end{array}$ & $\begin{array}{c}2.68 \pm \\
1.71\end{array}$ \\
\hline 16 & Soups & $\begin{array}{c}2.38 \\
\pm 0.81\end{array}$ & $\begin{array}{c}2.35 \\
\pm 0.74\end{array}$ & $\begin{array}{c}2.35 \\
\pm 0.85\end{array}$ & $\begin{array}{c}2.57 \\
\pm 0.74\end{array}$ & $\begin{array}{c}2.15 \\
\pm 0.84\end{array}$ & $\begin{array}{c}2.65 \\
\pm 0.58\end{array}$ & $\begin{array}{c}2.14 \\
\pm 0.91\end{array}$ & $\begin{array}{c}2.35 \\
\pm 0.81\end{array}$ & $\begin{array}{c}2.37 \\
\pm 0.82\end{array}$ & $\begin{array}{c}2.48 \\
\pm 0.78\end{array}$ & $\begin{array}{c}2.06 \\
\pm 0.60\end{array}$ & $\begin{array}{c}2.50 \\
\pm 0.85\end{array}$ \\
\hline 17 & Sport drinks & $\begin{array}{c}1.77 \pm \\
1.66\end{array}$ & $\begin{array}{c}1.12 \pm \\
1.36\end{array}$ & $\begin{array}{c}1.59 \pm \\
1.43\end{array}$ & $\begin{array}{c}2.09 \pm \\
1.75\end{array}$ & $\begin{array}{c}1.75 \pm \\
2.21\end{array}$ & $\begin{array}{c}2.20 \pm \\
1.59\end{array}$ & $\begin{array}{c}1.38 \pm \\
1.62\end{array}$ & $\begin{array}{c}1.78 \pm \\
1.71\end{array}$ & $\begin{array}{c}1.69 \pm \\
1.60\end{array}$ & $\begin{array}{c}2.02 \pm \\
1.73\end{array}$ & $\begin{array}{c}1.60 \pm \\
1.41\end{array}$ & $\begin{array}{c}1.83 \pm \\
1.74\end{array}$ \\
\hline 18 & Others drinks & $\begin{array}{c}0.97 \\
\pm 0.75\end{array}$ & $\begin{array}{c}1.19 \\
\pm 0.73\end{array}$ & $\begin{array}{c}0.86 \\
\pm 0.79\end{array}$ & $\begin{array}{c}1.00 \\
\pm 0.70\end{array}$ & $\begin{array}{c}0.68 \\
\pm 0.97\end{array}$ & $\begin{array}{c}0.84 \\
\pm 0.65\end{array}$ & $\begin{array}{c}1.09 \\
\pm 0.84\end{array}$ & $\begin{array}{c}0.95 \\
\pm 0.75\end{array}$ & $\begin{array}{c}1.01 \\
\pm 0.75\end{array}$ & $\begin{array}{c}0.90 \\
\pm 0.73\end{array}$ & $\begin{array}{c}1.73 \\
\pm 0.63\end{array}$ & $\begin{array}{c}0.71 \\
\pm 0.59\end{array}$ \\
\hline 19 & $\begin{array}{l}\text { Red meats and } \\
\text { eggs (alone or in } \\
\text { "casado") }\end{array}$ & $\begin{array}{c}0.67 \\
\pm 0.55\end{array}$ & $\begin{array}{c}0.73 \\
\pm 0.44\end{array}$ & $\begin{array}{c}0.46 \\
\pm 0.48\end{array}$ & $\begin{array}{c}0.88 \\
\pm 0.61\end{array}$ & $\begin{array}{c}0.73 \\
\pm 0.48\end{array}$ & $\begin{array}{c}0.80 \\
\pm 0.59\end{array}$ & $\begin{array}{c}0.55 \\
\pm 0.48\end{array}$ & $\begin{array}{c}0.66 \\
\pm 0.53\end{array}$ & $\begin{array}{c}0.67 \\
\pm 0.56\end{array}$ & $\begin{array}{c}0.68 \\
\pm 0.59\end{array}$ & $\begin{array}{c}0.79 \\
\pm 0.51\end{array}$ & $\begin{array}{c}0.62 \\
\pm 0.56\end{array}$ \\
\hline 20 & Legumes & $\begin{array}{c}0.63 \pm \\
0.37\end{array}$ & $\begin{array}{c}0.65 \pm \\
0.40\end{array}$ & $\begin{array}{c}0.61 \pm \\
0.35\end{array}$ & $\begin{array}{c}0.59 \pm \\
0.31\end{array}$ & $\begin{array}{c}0.78 \pm \\
0.47\end{array}$ & $\begin{array}{c}0.79 \pm \\
0.38\end{array}$ & $\begin{array}{c}0.49 \pm \\
0.30\end{array}$ & $\begin{array}{c}0.57 \pm \\
0.35\end{array}$ & $\begin{array}{c}0.64 \pm \\
0.37\end{array}$ & $\begin{array}{c}0.69 \pm \\
0.38\end{array}$ & $\begin{array}{c}0.51 \pm \\
0.30\end{array}$ & $\begin{array}{c}0.67 \pm \\
0.39\end{array}$ \\
\hline 21 & $\begin{array}{c}\text { Starchy } \\
\text { vegetales }\end{array}$ & $\begin{array}{c}0.31 \pm \\
0.24\end{array}$ & $\begin{array}{c}0.39 \pm \\
0.14\end{array}$ & $\begin{array}{c}0.24 \pm \\
0.29\end{array}$ & $\begin{array}{c}0.24 \pm \\
0.34\end{array}$ & $\begin{array}{c}0.28 \pm \\
0.31\end{array}$ & $\begin{array}{c}0.34 \pm \\
0.29\end{array}$ & $\begin{array}{c}0.27 \pm \\
0.17\end{array}$ & $\begin{array}{c}0.28 \pm \\
0.24\end{array}$ & $\begin{array}{c}0.32 \pm \\
0.24\end{array}$ & $\begin{array}{c}0.31 \pm \\
0.23\end{array}$ & $\begin{array}{c}0.49 \pm \\
0.34\end{array}$ & $\begin{array}{c}0.24 \pm \\
0.15\end{array}$ \\
\hline 22 & $\begin{array}{c}\text { Sweets and } \\
\text { creamy ice cream }\end{array}$ & $\begin{array}{c}0.30 \pm \\
0.16\end{array}$ & $\begin{array}{c}0.34 \pm \\
0.15\end{array}$ & $\begin{array}{c}0.30 \pm \\
0.18\end{array}$ & $\begin{array}{c}0.30 \pm \\
0.14\end{array}$ & $\begin{array}{c}0.28 \pm \\
0.16\end{array}$ & $\begin{array}{c}0.23 \pm \\
0.14\end{array}$ & $\begin{array}{c}0.37 \pm \\
0.15\end{array}$ & $\begin{array}{c}0.30 \pm \\
0.16\end{array}$ & $\begin{array}{c}0.31 \pm \\
0.16\end{array}$ & $\begin{array}{c}0.30 \pm \\
0.16\end{array}$ & $\begin{array}{c}0.24 \pm \\
0.12\end{array}$ & $\begin{array}{c}0.33 \pm \\
0.17\end{array}$ \\
\hline 23 & $\begin{array}{c}\text { Non - starchy } \\
\text { vegetales }\end{array}$ & $\begin{array}{c}0.21 \pm \\
0.16\end{array}$ & $\begin{array}{c}0.30 \pm \\
0.20\end{array}$ & $\begin{array}{c}0.16 \pm \\
0.13\end{array}$ & $\begin{array}{c}0.26 \pm \\
0.15\end{array}$ & $\begin{array}{c}0.19 \pm \\
0.14\end{array}$ & $\begin{array}{c}0.24 \pm \\
0.13\end{array}$ & $\begin{array}{c}0.19 \pm \\
0.18\end{array}$ & $\begin{array}{c}0.19 \pm \\
0.16\end{array}$ & $\begin{array}{c}0.22 \pm \\
0.16\end{array}$ & $\begin{array}{c}0.23 \pm \\
0.15\end{array}$ & $\begin{array}{c}0.19 \pm \\
0.13\end{array}$ & $\begin{array}{c}0.22 \pm \\
0.17\end{array}$ \\
\hline 24 & Fruits & $\begin{array}{c}0.08 \pm \\
0.02\end{array}$ & $\begin{array}{c}0.094 \pm \\
0.018\end{array}$ & $\begin{array}{c}0.08 \pm \\
0.02\end{array}$ & $\begin{array}{c}0.08 \pm \\
0.03\end{array}$ & $\begin{array}{c}0.07 \pm \\
0.03\end{array}$ & $\begin{array}{c}0.07 \pm \\
0.02\end{array}$ & $\begin{array}{c}0.08 \pm \\
0.02\end{array}$ & $\begin{array}{c}0.08 \pm \\
0.02\end{array}$ & $\begin{array}{c}0.08 \pm \\
0.03\end{array}$ & $\begin{array}{c}0.08 \pm \\
0.02\end{array}$ & $\begin{array}{c}0.06 \pm \\
0.02\end{array}$ & $\begin{array}{c}0.08 \pm \\
0.20\end{array}$ \\
\hline 25 & Energy drinks & $\begin{array}{c}0.00 \pm \\
0.00\end{array}$ & $\begin{array}{c}0.00 \pm \\
0.00\end{array}$ & $\begin{array}{c}0.00 \pm \\
0.00\end{array}$ & $\begin{array}{c}0.00 \pm \\
0.00\end{array}$ & $\begin{array}{c}0.00 \pm \\
0.00\end{array}$ & $\begin{array}{c}0.00 \pm \\
0.00\end{array}$ & $\begin{array}{c}0.00 \pm \\
0.00\end{array}$ & $\begin{array}{c}0.00 \pm \\
0.00\end{array}$ & $\begin{array}{c}0.00 \pm \\
0.00\end{array}$ & $\begin{array}{c}0.00 \pm \\
0.00\end{array}$ & $\begin{array}{c}0.00 \pm \\
0.00\end{array}$ & $\begin{array}{c}0.00 \pm \\
0.00\end{array}$ \\
\hline
\end{tabular}

a The proportion (\%) of sodium consumed is defined as the sum of the amount from each specific food category divided by the sum from all food categories by 100. b Rank based on population proportions of sodium consumed for the overall Costa Rican students. Columns for other groups are ordered by this ranking. 
In the case of women (9.62), as well as children from 7 to 9 years old (8.54) and those who have excess weight (overweight or obese) (9.17), the second highest contributor of sodium was the group of fried prepared pastries and sandwiches. While this food group was the third highest contributor among the rest of participants of all ages (8.40), of all the socioeconomic strata examined (low: 8.21; medium: 8.55 and high: 8.27 ) and of those who were not overweight or obese (8.14) (Table 5).

\section{Discussion}

The daily sodium intake without considering the addition of salt to the served plate or food, among children and adolescents from 7 to 18 years old, exceeds international recommendations, regardless the demographic subgroups examined (age, sex and socioeconomic status) and nutritional status. This mean daily intake between 7.5 and 8.5 grams is mainly related to the sodium-dense diet. In Costa Rica, young as well as adult population exceeds sodium consumption, both almost doubling international standards.

However, in this study, an intake of $\geq 5$ g of salt per day was defined as excessive for children older than 7 years. This limit was established arbitrarily according to the maximum recommended by WHO for adults and children between 7 and 16 years [23], since there is no worldwide consensus on the delimitation in children of optimal or high intake [24] and there are very few data on salt intake in this group age worldwide [25].

The 2015-2020 Dietary Guidelines for Americans recommend that Americans consume less than $2300 \mathrm{mg}$ sodium per day and suggest that specific subgroups should limit sodium intake. The Institute of Medicine's indicates that the tolerable upper intake level for sodium for children is 1900 (4 - 8 y); 2200 (9 - 13 y) and $2300 \mathrm{mg} /$ day for those aged 14 years and older [1].

The integration of the available evidence and associated uncertainties, the EFSA Panel on Nutrition, Novel Foods and Food Allergens (NDA) considers that a sodium intake of $2 \mathrm{~g} /$ day represents a level of sodium for which there is sufficient confidence in a reduced risk of CVD in the general adult population. In addition, a sodium intake of $2 \mathrm{~g}$ /day is likely to allow most of the general adult population to maintain sodium balance. Therefore, the EFSA Panel considers that $2 \mathrm{~g}$ sodium/day is a safe and adequate intake for the general EU population of adults. Sodium intakes that are considered safe and adequate for children are extrapolated from the value for adults, adjusting for their respective energy requirement and including a growth factor, and are as follows for children: $1.1(1-3 \mathrm{y}), 1.3(4-6 \mathrm{y}), 1.7(7-10 \mathrm{y})$ and $2 \mathrm{~g} /$ day for $11-17$ years old. Therefore, the sodium density of the population in this study almost doubles the suggested amount. Also the average intake reported in this study is 3 - 4 times higher than the one recommended by the EFSA Panel on Nutrition, Novel Foods and Food Allergens (NDA) [26].

On the other hand, the average daily sodium intake among school children 
from 10 to 12 years old in the present study was approximately $600 \mathrm{mg}$ higher than that of younger school children ( $7-9 y)$, similar to those in the older subgroup (16 - $18 \mathrm{y}$ ), whose average intake ranged between $7.5-10 \mathrm{~g}$ salt. These numbers are in between the averages of salt consumption reported in the United States of America and some European studies with samples of children and adolescents. In the USA, using a 24-hour diet reminder used in the NHANES 2011-2012 survey with 2142 children and adolescents (6 - 18 y), salt consumption was $8.1 \mathrm{~g}$ per day [1]; in Spain, a study carried out in 2014 with 205 children between 7 and 11 years old using the gold standard methodology, 24-hour urine sodium excretion, reported 7.8 grams of daily intake salt [27]; in Italy, a study included 1424 children and adolescents between 6 and 18 years old and collected a 24-hour urine sample, finding a salt intake of $7.1 \mathrm{~g}$ per day [28]. Other studies carried out in Portugal [29] that used dietary registration and 24-hour urinary excretion, reported salt consumption of $<7 ; 6.6 \mathrm{~g}$ and $5.9 \mathrm{~g} /$ day, respectively. Swiss children, $62 \%$ had salt excretions above the maximum intake recommendations ( $\geq 2 \mathrm{~g}$ for up to 6 years and $\geq 5 \mathrm{~g}$ per day from 7 to 16 years) [30].

On average, children and adolescents consumed 1.6 to $1.8 \mathrm{mg} / \mathrm{kcal}$, a much higher amount than $1 \mathrm{mg}$ sodium/ kcal, proposed by Guenther et al. (2013) [31].

Regarding the food groups that contribute the most to sodium intake, in the present investigation, it was found that more than $60 \%$ of sodium comes from 10 food groups. The largest contributor was the group of meats with visible or fried fat (alone or in a "casado"), where fried chicken stands out for its low cost compared to other meats and for the use of salt and seasonings that give a characteristic flavor to fried chicken, which, judging by its consumption, is of great preference among children and adolescents [32] According to estimates done by the National Chamber of Poultry Farmers of Costa Rica (CANAVI) in 2015, per capita intake of chicken meat was $23.3 \mathrm{~kg}$, ranking above beef and pork [33]. This could be attributed to the reduction in production costs and the efficiency that has been achieved, resulting in a decrease of consumer prices [34]. Followed by this food group, the four that contributed the most were: soy or spices (Salsa Lizano $^{\oplus}$ ) sauces, fried prepared pastries and sandwiches, fast foods and tomato or pink sauces.

For Swiss children, the main sources of salt/sodium intake were pasta, potatoes and rice (23\% of the total intake), cakes (16\%), bread (16\%) and cured meats or sausages (10\%) [30], similar to what was found in this Costa Rican study regarding the group of fried prepared pastries and sandwiches. Also similar to what has also been found in some European countries, despite regional and cultural differences, the foods that provide the greatest amounts of salt are grain-based products (including bread), meat products and dairy products [35], but differing from their Costa Rican counterparts in the present study regarding the consumption of sauces.

In addition, $34 \%$ of Swiss children reported adding salt to their served plate (at the table) [30]; this proportion was higher in the participants from Costa Rica (49.4\%). Near $38.8 \%$ reported that they usually add from 1 to 2 days a week, at 
least one "pinch" of salt to their served plate or some foods such as fruits (mango, pineapple), sour cream, avocado, among others. One in ten Costa Rican children and adolescents (10.6\%) reported that this addition of salt (pinch) occurs every 3 - 4 days a week.

However, in the present study, variations were found in the ten food groups that contribute most to higher sodium consumption, according to age, sex, socioeconomic level and nutritional status subgroups. It is striking that in children from 7 to 9 years old, the third contributor was the group of tomato or pink sauce (tomato sauce and mayonnaise mix), and the fourth was the group of salted seeds, which is not among the five first food groups in the general sodium list (it is the seventh position). The fast food group was fourth in the sodium list of the general population and was also the fourth contributor in children between 10 and 12 years old, adolescents between 16 and 18 years old, men, those from the three socioeconomic strata examined and for those who are not overweight or obese; while the fast food group was the sixth highest contributor of sodium for children from 7 to 9 years old.

Otherwise, the food groups that contributed the least to sodium intake were legumes, starchy vegetables and tropical roots, sweets and creamy ice cream, non-starchy vegetables and fruits. The majority of these food groups was identified on the study by Guevara D. et al., as deficient in consumption (legumes, fruits, non-mealy vegetables and fish) in a sample of 798 participants between 15 and 65 years old from the urban area of Costa Rica [36]. Likewise, Moreno's study (2013) with 79 Costa Rican boys and 74 girls from 11 to 14 years old, determined that $100 \%$ of them do not fulfill the recommended daily consumption of fruits and vegetables, as it was very low [37]. Data from the second National Youth Survey Costa Rica 2013 [38], where 2800 men and women between 15 and 35 years old participated, reported that $64.2 \%$ had an inadequate (deficient) consumption of fruits and vegetables.

The food groups identified as of deficient consumption in the Costa Rican population and which were the ones that contributed less to its intake in the present study, have been recognized in the scientific literature as protectors (mainly legumes, non-starchy vegetables and fruits) of the main chronic diseases prevalent in Costa Rica, such as obesity, diabetes and high blood pressure. While the food groups: fried chicken; soy or spices or tomato sauces; fried prepared pastries and sandwiches; fast foods; processed meats/sausages; salty cookies; snacks in small packages; popcorn and ripe or creamy cheeses have been identified as a risk for these diseases due to their association with their high fat and/or sodium content [32]. These processed products are offered mostly by international restaurants aimed to children, adolescents and their families [39].

Another aspect to consider that could be favoring the intake of sodium-dense diets, in addition to the rise of consumption of fast-food restaurants specializing in burgers, pizza, or chicken and highly processed food is the palatability and increase in convenience foods. In fact, the consumption of these popular foods among young people could explain the more sodium-dense diets consumed by 
children over 9 years old in Costa Rica. Childhood and adolescence are key periods of an individual's life during which eating habits are formed [40] and food preferences are determined by the first eating experiences [5], so limiting salt intake during childhood has the potential to prevent lifelong hypertension and its associated consequences [41].

In addition, it has been estimated that a high salt intake causes 1.65 million deaths from cardiovascular diseases per year [42], mainly due to its effect on blood pressure. Increasing sodium intake is associated with increasing blood pressure, whereas low sodium intake results in increased renin and aldosterone levels. The high sodium intake and the increase in blood pressure levels are related to water retention, increase in systemic peripheral resistance, alterations in the endothelial function, changes in the structure and function of large elastic arteries, modification in sympathetic activity, and in the autonomic neuronal modulation of the cardiovascular system [43] [44].

Cardiovascular diseases lead the main causes of death in Costa Rica [45] [46]. Sodium reduction is an important strategy to reduce high blood pressure and help prevent cardiovascular disease. High salt intake has been associated with high blood pressure in both adults [47] [48] [49] and children [50] and there is evidence that high blood pressure can cause vascular damage starting at an early age [3] [51] [52] [53].

Evaluating the level of salt intake in children and adolescents is, therefore, of clinical and public health relevance and the evidence provide by this study highlights how important is that primary schools and high schools in Costa Rica begin a strict control of compliance with the maximum sodium allowed in the food supply (food and beverages) [54]. National efforts should be done in multiple sectors to reduce excessive consumption of sodium in the general population and specifically in children and adolescents, as other countries have done, considering the food offered in schools [55] and those competitive foods and beverages that are not offered in school meal programs [56], but in large fast food restaurants, among others.

According to the WHO (2013) there are two key strategies to reduce sodium intake in the population: 1) voluntary or mandatory reformulation strategies and 2) communication with consumers to educate, raise awareness and motivate them to make desirable behavioral changes [57]. Furthermore, it should be considered that reformulation policies to reduce salt in manufacturing foods can be highly profitable [58].

The indicated strategies could be applied in Costa Rica to reduce sodium content not only in products and foods with high sodium concentrations (for example, meats with visible or fried fat, fried chicken, sauces, processed meats and sausages), but also in those with moderate contents that young Costa Ricans consume frequently and in large quantities, such as the fried prepared pastries, sandwiches, fast foods, cereals, "gallo pinto", salted seeds, salty cookies, snacks in small packages and popcorn, among others.

Since 2016, Costa Rica agreed voluntary sodium reduction goals in six key 
processed food categories (or 23 subcategories) because of its contribution of sodium to the diet of the general population: condiments, sauces, cookies, pastries, sausages and breads. All these categories, except one (breads), are the most consumed by children and adolescents. Compliance with the national sodium reduction targets was evaluated in 2018. A significant reduction in average sodium content was found in only 3 of the 19 subcategories (cakes, tomato-based sauces, and tomato paste). No subcategories had statistically significant increases in mean sodium levels, but seasonings for sides/mains, ham, and sausage categories were at least $15 \%$ higher in sodium. Compliance with the national sodium targets among all foods increased from 80 in 2015 to $87 \%$ in 2018. The results demonstrate that it is feasible to reduce the sodium content in packaged foods in Costa Rica, but more work is needed to continually support a gradual reduction of sodium in packaged foods, including more stringent sodium targets [59].

The United States of America, through the Live-Well program, seeks that participating restaurants offer healthy meals to children and adolescents, encouraging increased consumption of fruits, non-starchy vegetables and whole grains, and decreased intake of added sugars and sodium [60].

On the other hand, several companies in New York (USA) have been gradually reducing the sodium content in their products [61] and in June 2016 the US Food and Drug Administration issued a preliminary guidance for the food industry with the purpose that this sector voluntary decreases its sodium content in the products [62].

In addition, groups such as the American Heart Association, the American Academy of Pediatrics, the Academy of Nutrition and Dietetics, and the 2015-2020 Dietary Guidelines for Americans reviewed the evidence and continue to support strategies to encourage a healthy diet, including lower sodium intake between children and adolescents [63] [64].

Now, the option of taxing unhealthy foods, for example with high sodium density, may be hopeful, but the change in the food supply towards prices that encourage the consumption of healthier diets and the decrease in demand for less healthy products is not simple and will not happen right away. Likewise, companies in the food industry must be incentivized to market the components of healthy diets; this could be primarily through selective taxes and subsidies, marketing controls, food quality regulations, consumer education and in the medium term, consumers' desires to combine healthier foods with their continued pursuit of convenience in the face of their busy work schedules. At the end, the food industry in general, and specifically in Latin America and the Caribbean, is expected to move towards profitable solutions, that is, those demanded by a large volume of smart (educated) consumers [30] [65] [66] [67] [68].

\section{Limitations}

There are three main limitations in our analysis. First, the intake estimation method used was the frequency of consumption, which is useful to provide in- 
formation on the food groups and typical foods consumed. It reflects habitual food consumption but the intake quantification is not as accurate as in reminders or other records. Although an open section was included in the frequency of consumption questionnaire for students to record the intake of other foods not included in the list. The inaccuracies derived from the fact that the food list is incomplete, which could lead to mistakes in the estimates of the frequency of consumption and the size of the portion, since the precision of the information is based on the memory bias of the person who answered the questionnaire. Also, the information could be biased because the participant may have provided answers of social convenience, therefore overestimating the consumption of some foods and underestimating others. Only the students from first to third year of school were administered the frequency of consumption through an interview, which reduces biases at least in this part of the study sample. In the present study to evaluate the total sodium intake, the gold standard was not available due to lack of financing. However, 24-hour urine excretion of sodium is not a complete or absolute method, since it does not report on the contribution of specific foods or food groups to total sodium intake. In addition, taking the 24-hour urine sample in children and adolescents can be complicated because of the care they have to take. Therefore, some studies in adults and children that have used the gold standard to measure the excretion of sodium have been mixed with dietary methods [64].

Second, a single method was not used to estimate the sodium content of the foods and products analyzed, so there could be variations in the estimation of sodium per serving of food or product. However, because the analytical method is the most accurate and reliable and because the sodium contents resulting from this method were directly determined in the foods consumed by these children and adolescents, the data from the direct method were prioritized over the indirect methods reported in the food composition bases [21].

Third, the data used from the indirect methods, could overestimate or underestimate the sodium content, as the food formulation does not estimates with certainty that some have undergone modifications after the report of the amount of sodium in the food composition bases consulted [21].

\section{Conclusions}

To our knowledge, this is the first study to assess the average sodium intake among children and adolescents in Costa Rica and it is related to sodium-dense foods, which make up the pattern of food consumption of the participating population. The results support the high level of sodium consumed by the Costa Rican population, either adults or young, as well as the need for food providers, as well as the food industry sectors related to meats with visible or fried fat, fried chicken, soy or spices (Salsa Lizano ${ }^{\circ}$ ) sauces, fried prepared pastries and sandwiches, fast foods, tomato or pink sauces, cereals and/or "gallo pinto"; salted seeds, processed meats/sausages, salty cookies and snacks in small packages, re- 
duce the sodium content in your products. On the other hand, schools and parents should discourage the addition of salt to prepared foods and fruits. Furthermore, they should promote the intake of legumes, vegetables and fruits.

These results justify carrying out social marketing campaigns that include educational processes with a meaning for children, adolescents and families, in a way that these sectors of the population are motivated to gradually modify eating habits related to reducing the addition of sauces, seasonings and common salt in food preparation and in those foods and preparations already served. If the habit of adding "pinches" of salt to the plate or food is gradually reduced until elimination, the habit of children and adolescents in Costa Rica would reduce the consumption of salt per day from 1 to 2 grams and this decrease would be bigger if the elimination of the consumption of sauces that are often used among this young population (soy or spices-Salsa Lizano ${ }^{\oplus}$, tomato or pink sauces-tomato sauce and mayonnaise mix) will be gradually reached, which would contribute to this population approaching to meet the recommendation of maximum salt intake (5 g per day).

\section{Ethical Approval}

All procedures performed were in accordance with the ethical standards involving human participants of the institutional research committee and with the 1964 Helsinki Declaration and its later amendments or comparable ethical standards.

\section{Informed Consent and Assent Forms}

Informed assent and consent forms were obtained from all individual participants included in the study and their parents.

\section{Conflicts of Interest}

The authors declare no conflicts of interest regarding the publication of this paper.

\section{References}

[1] Quader, Z.S., Gillespie, C., Sliwa, S.A., et al. (2017) Sodium Intake among US School-Aged Children: National Health and Nutrition Examination Survey, 2011-2012. Journal of the Academy of Nutrition and Dietetics, 117, 39-47.E5. https://doi.org/10.1016/j.jand.2016.09.010

[2] Kit, B.K., Kuklina, E., Carroll, M.D., Ostchega, Y., Freedman, D.S. and Ogden, C.L. (2015) Prevalence of and Trends in Dyslipidemia and Blood Pressure among Us Children and Adolescents, 1999-2012. JAMA Pediatrics, 169, 272-279. https://doi.org/10.1001/jamapediatrics.2014.3216

[3] Chen, X. and Wang, Y. (2008) Tracking of Blood Pressure from Childhood to Adulthood: A Systematic Review and Meta-Regression Analysis. Circulation, 117, 3171-3180. https://doi.org/10.1161/CIRCULATIONAHA.107.730366

[4] Effect of Lower Sodium Intake on Health: Systematic Review and Meta-Analyses: 
Database of Abstracts of Reviews of Effects (DARE): Quality-Assessed Reviews. NCBI Bookshelf. https://www.ncbi.nlm.nih.gov/books/NBK132099/

[5] Mennella, J.A. (2014) Ontogeny of Taste Preferences: Basic Biology and Implications for Health1-5. The American Journal of Clinical Nutrition, 99, 704S-711S. https://doi.org/10.3945/ajcn.113.067694

[6] Institude of Medicine (2005) Dietary Reference Intakes for Water, Potassium, Sodium, Chloride, and Sulfate. National Academies Press, Washington DC.

[7] Strohm, D., Bechthold, A., Ellinger, S., Leschik-Bonnet, E., Stehle, P. and Heseker, H. (2018) Revised Reference Values for the Intake of Sodium and Chloride. Annals of Nutrition and Metabolism, 72, 12-17. https://doi.org/10.1159/000484355

[8] DACH-Referenzwerte-Schweizerische Gesellschaft für Ernährung. http://www.sge-ssn.ch/grundlagen/lebensmittel-und-naehrstoffe/naehrstoffempfehl ungen/dachreferenzwerte/

[9] Odphp (2015) 2015-2020 Dietary Guidelines for Americans. http://health.gov/dietaryguidelines/2015/guidelines/

[10] Gamboa-Gamboa, T., Blanco-Metzler, A., Vandevijvere, S., Ramirez-Zea, M. and Kroker-Lobos, M.F. (2019) Nutritional Content According to the Presence of Front of Package Marketing Strategies: The Case of Ultra-Processed Snack Food Products Purchased in Costa Rica. Nutrients, 11, 2738.

https://doi.org/10.3390/nu11112738

[11] José, J.M. (1997). La construcción de índices. CRE de la Universidad de Costa Rica.

[12] WHO (2014) WHO Child Growth Standards: Methods and Development. WHO, Geneva.

[13] Güngör, N.K. (2014) Overweight and Obesity in Children and Adolescents. The Journal of Clinical Research in Pediatric Endocrinology, 6, 129-143. https://doi.org/10.4274/jcrpe.1471

[14] Núñez-Rivas, H.P., Holst-Schumacher, I. and Campos-Saborío, N. (2020) New Diet Quality Index for Children and Adolescents in Costa Rica. Nutricion Hospitalaria, 37, 65-72. https://doi.org/10.20960/nh.02695

[15] Haile, B., Neme, K. and Belachew, T. (2017) Evolution of Human Diet and Effect of Globalization on Regional Diet with Emphasis to the Mediterranean Diet. Nutrition \& Food Science, 47, 869-883. https://doi.org/10.1108/NFS-02-2017-0017

[16] Mariz, L.S., Enders, B.C., Santos, V.E.P., Tourinho, F.S.V. and Vieira, C.N.K. (2015) Causas de obesidade infantojuvenil: Reflexões segundo a teoria de Hannah Arendt. Texto \& Contexto Enfermagem, 24, 891-897. https://doi.org/10.1590/0104-07072015002660014

[17] Chinnock, A. and Castro, R. (2014) Manual Fotográfico de Porciones de Alimentos Comunes en Costa Rica. San José: Universidad de Costa Rica.

[18] Chaverri, M., Rodríguez, M.A. and Chinnock, A. (2001) Peso de Medidas Caseras y Porciones de Alimentos y Preparaciones Comunes en Costa Rica. Programa de Análisis Dietético y Valor Nutricional. San José: Escuela de Nutrición, Universidad de Costa Rica.

[19] Sodio en panes y snacks de mayor consumo en Costa Rica. Contenido basal y verificación del etiquetado nutricional. https://www.alanrevista.org/ediciones/2015/1/art-5/

[20] Blanco-Metzler, A., Heredia-Blonval, K., Montero-Campos, M. and Benavides, K. (2016) Implementación de un programa poblacional para reducir el consumo de sal/sodio en Costa Rica: Informe técnico final (1 de abril, 2012-30 de Septiembre, 2016). 
[21] Tabla de Composición de Alimentos de Centroamérica. INCAP. http://www.sennutricion.org/es/2013/05/01/tabla-de-composicin-de-alimentos-de-c entroamrica-incap

[22] Food Data Central. https://fdc.nal.usda.gov/

[23] WHO (2012) Sodium Intake for Adults and Children. http://www.ncbi.nlm.nih.gov/pubmed/23658998

[24] Mente, A., O’Donnell, M., Rangarajan, S., et al. (2016) Associations of Urinary Sodium Excretion with Cardiovascular Events in Individuals with and without Hypertension: A Pooled Analysis of Data from Four Studies. The Lancet, 388, 465-475. https://doi.org/10.1016/S0140-6736(16)30467-6

[25] Olsen, M.H., Angell, S.Y., Asma, S., et al. (2016) A Call to Action and A Lifecourse Strategy to Address the Global Burden of Raised Blood Pressure on Current and Future Generations: The Lancet Commission on Hypertension. The Lancet, 388, 2665-2712. https://doi.org/10.1016/S0140-6736(16)31134-5

[26] European Food Safety Authority (EFSA) (2019) Outcome of Public Consultations on the Scientific Opinions of the EFSA Panel on Nutrition, Novel Foods and Food Allergens (NDA) on Dietary Reference Values for Sodium and Chloride. EFSA Supporting Publications, 16, 1679E. https://doi.org/10.2903/sp.efsa.2019.EN-1679

[27] Aparicio, A., Rodríguez-Rodríguez, E., Cuadrado-Soto, E., Navia, B., López-Sobaler, A.M. and Ortega, R.M. (2017) Estimation of Salt Intake Assessed by Urinary Excretion of Sodium over $24 \mathrm{H}$ in Spanish Subjects Aged 7-11 Years. European Journal of Nutrition, 56, 171-178. https://doi.org/10.1007/s00394-015-1067-y

[28] Campanozzi, A., Avallone, S., Barbato, A., et al. (2015) High Sodium and Low Potassium Intake among Italian Children: Relationship with Age, Body Mass and Blood Pressure. PLOS ONE, 10, e0121183.

https://doi.org/10.1371/journal.pone.0121183

[29] Oliveira, A.C., Padrão, P., Moreira, A., et al. (2015) Potassium Urinary Excretion and Dietary Intake: A Cross-Sectional Analysis in 8 - 10 Year-Old Children. BMC Pediatrics, 15, Article No. 60. https://doi.org/10.1186/s12887-015-0374-Z

[30] Rios-Leyvraz, M., Bovet, P., Bochud, M., et al. (2019) Estimation of Salt Intake and Excretion in Children in One Region of Switzerland: A Cross-Sectional Study. European Journal of Nutrition, 58, 2921-2928. https://doi.org/10.1007/s00394-018-1845-4

[31] Guenther, P.M., Lyon, J.M.G. and Appel, L.J. (2013) Modeling Dietary Patterns to Assess Sodium Recommendations for Nutrient Adequacy. The American Journal of Clinical Nutrition, 97, 842-847. https://doi.org/10.3945/ajcn.112.047779

[32] Heredia-Blonval, K., Blanco-Metzler, A., Montero-Campos, M. and Dunford, E.K. (2014) The Salt Content of Products from Popular Fast-Food Chains in Costa Rica. Appetite, 83, 173-177. https://doi.org/10.1016/j.appet.2014.08.027

[33] Vargas, A., et al. (2018) Prácticas efectivas para la reducción de impactos por eventos climáticos en Costa Rica. Ficha técnica sector productivo avícola, San José, Costa Rica, $94 \mathrm{p}$.

[34] Benavides, H. (2007) El entorno internacional del sector avícola centroamericano. Instituto Interamericano de Cooperación para la Agricultura, San José, Costa Rica, $58 \mathrm{p}$.

[35] Kloss, L., Meyer, J.D., Graeve, L. and Vetter, W. (2015) Sodium Intake and Its Reduction by Food Reformulation in the European Union-A Review. NFS Journal, 1, 9-19. https://doi.org/10.1016/j.nfs.2015.03.001

[36] Guevara-Villalobos, D., Céspedes-Vindas, C., Flores-Soto, N., et al. (2019) Original 
Hábitos Alimentarios de La Población Urbana Costarricense (Food Habits of Urban Costa Rican Population). Acta Médica Costarricense, 61, 152-159.

http://www.scielo.sa.cr/scielo.php?script=sci arttext\&pid=S0001-600220190004001 $\underline{52 \& \operatorname{lng}=\mathrm{en}}$

[37] Moreno, R.M.I.M. (2013) Relación entre el consumo de frutas, vegetales y alimentos altos en grasa, con el nivel de actividad física, en niñas y niños costarricenses en edad escolar, pertenecientes la provincia de San José.

http://hdl.handle.net/11056/11311

[38] Consejo de la Persona Joven. (2013). Segunda Encuesta Nacional de Juventudes. San José, Costa Rica: AJM S.A.

[39] Ahuja, J.K.C., Wasswa-Kintu, S., Haytowitz, D.B., et al. (2015) Sodium Content of Popular Commercially Processed and Restaurant Foods in the United States. Preventive Medicine Reports, 2, 962-967. https://doi.org/10.1016/j.pmedr.2015.11.003

[40] Lipsky, L.M., Haynie, D.L., Liu, D., et al. (2015) Trajectories of Eating Behaviors in a Nationally Representative Cohort of U.S. Adolescents during the Transition to Young Adulthood. International Journal of Behavioral Nutrition and Physical Activity, 12, Article No. 138. https://doi.org/10.1186/s12966-015-0298-x

[41] Labarthe, D.R. (1999) Prevention of Cardiovascular Risk Factors in the First Place. Preventive Medicine, 29, S72-S78. https://doi.org/10.1006/pmed.1999.0539

[42] Mozaffarian, D., Fahimi, S., Singh, G.M., et al. (2014) Global Sodium Consumption and Death from Cardiovascular Causes. The New England Journal of Medicine, 371, 624-634. https://doi.org/10.1056/NEJMoa1304127

[43] O’Donnell, M., Mente, A. and Yusuf, S. (2015) Sodium Intake and Cardiovascular Health. Circulation Research, 116, 1046-1057. https://doi.org/10.1161/CIRCRESAHA.116.303771

[44] Grillo, A., Salvi, L., Coruzzi, P., Salvi, P. and Parati, G. (2019) Sodium Intake and Hypertension. Nutrients, 11, 1970. https://doi.org/10.3390/nu11091970

[45] World Health Organization (2018) Noncommunicable Diseases Country Profiles. World Health Organization, Geneva. http://www.who.int/iris/handle/10665/274512

[46] Wong, F. and Mcclure, R. (2016) Vigilancia de los factores de riesgo cardiovascular.

[47] He, F.J., Li, J. and Macgregor, G.A. (2013) Effect of Longer Term Modest Salt Reduction on Blood Pressure: Cochrane Systematic Review and Meta-Analysis of Randomised Trials. BMJ, 346, f1325. https://doi.org/10.1136/bmj.f1325

[48] Graudal, N.A., Hubeck-Graudal, T. and Jurgens, G. (2017) Effects of Low Sodium Diet versus High Sodium Diet on Blood Pressure, Renin, Aldostero,Ne, Catecholamines, Cholesterol, and Triglyceride. Cochrane Database of Systematic Reviews, No. 4. Article No. CD004022. https://doi.org/10.1002/14651858.CD004022.pub4

[49] Meneton, P., Jeunemaitre, X., De Wardener, H.E. and Macgregor, G.A. (2005) Links between Dietary Salt Intake, Renal Salt Handling, Blood Pressure, and Cardiovascular Diseases. Physiological Reviews, 85, 679-715.

https://doi.org/10.1152/physrev.00056.2003

[50] Rios-Leyvraz, M., Bloetzer, C., Chatelan, A., et al. (2019) Sodium Intake and Blood Pressure in Children with Clinical Conditions: A Systematic Review with Meta-Analysis. The Journal of Clinical Hypertension, 21, 118-126. https://doi.org/10.1111/jch.13436

[51] Chiolero, A., Cachat, F., Burnier, M., Paccaud, F. and Bovet, P. (2007) Prevalence of Hypertension in Schoolchildren Based on Repeated Measurements and Association 
with Overweight. The Journal of Clinical Hypertension, 25, 2209-2217. https://doi.org/10.1097/HJH.0b013e3282ef48b2

[52] Mccrindle, B.W. (2010) Assessment and Management of Hypertension in Children and Adolescents. Nature Reviews Cardiology, 7, 155-163.

https://doi.org/10.1038/nrcardio.2009.231

[53] Chiolero, A., Bovet, P. and Paradis, G. (2013) Screening for Elevated Blood Pressure in Children and Adolescents: A Critical Appraisal. JAMA Pediatrics, 167, 266-273. https://doi.org/10.1001/jamapediatrics.2013.438

[54] Ministerio de Educación Pública. (2011) Decreto Ejecutivo No 36910-MEP-S, Reglamento para el funcionamiento y administración del servicio de soda en los centros educativos públicos. San José, Costa Rica.

[55] Food and Nutrition Service (FNS) and USDA (2012) Nutrition Standards in the National School Lunch and School Breakfast Programs. Final Rule. Federal Register, 77, 4088-4167. http://www.ncbi.nlm.nih.gov/pubmed/22359796

[56] Food and Nutrition Service and USDA (2016) National School Lunch Program and School Breakfast Program: Nutrition Standards for All Foods Sold in School As Required by the Healthy, Hunger-Free Kids Act of 2010. Final Rule and Interim Final Rule. Federal Register, 81, 50131-50151. http://www.ncbi.nlm.nih.gov/pubmed/27476195

[57] WHO (2015) Global Action Plan for the Prevention and Control of NCDs 2013-2020. WHO, Geneva.

[58] Wang, G. and Labarthe, D. (2011) The Cost-Effectiveness of Interventions Designed to Reduce Sodium Intake. Journal of Hypertension, 29, 1693-1699. https://doi.org/10.1097/HJH.0b013e328349ba18

[59] Vega-Solano, J., Blanco-Metzler, A., Benavides-Aguilar, K.F. and Arcand, J.A. (2019) An Evaluation of the Sodium Content and Compliance with the National Sodium Reduction Targets among Packaged Foods Sold in Costa Rica in 2015 and 2018. Nutrients, 11, 2226. https://doi.org/10.3390/nu11092226

[60] Kids Livewell. National Restaurant Association. https://restaurant.org/kidslivewell

[61] Sodium Initiatives-NYC Health.

https://www1.nyc.gov/site/doh/health/health-topics/national-salt-reduction-initiati ve.page

[62] Draft Guidance for Industry: Target Mean and Upper Bound Concentrations for Sodium in Commercially Processed, Packaged, and Prepared Foods for Voluntary Sodium Reduction Goals|FDA.

https://www.fda.gov/regulatory-information/search-fda-guidance-documents/draftguid-

ance-industry-target-mean-and-upper-bound-concentrations-sodium-commerciall y-processed

[63] Gidding, S.S., Dennison, B.A., Birch, L.L., et al. (2006) Dietary Recommendations for Children and Adolescents: A Guide for Practitioners. Pediatrics, 117, 544-559. https://doi.org/10.1542/peds.2005-2374

[64] Ogata, B.N. and Hayes, D. (2014) Position of the Academy of Nutrition and Dietetics: Nutrition Guidance for Healthy Children Ages 2 to 11 Years. Journal of the Academy of Nutrition and Dietetics, 114, 1257-1276. https://doi.org/10.1016/j.jand.2014.06.001

[65] Popkin, B.M. and Reardon, T. (2018) Obesity and the Food System Transformation in Latin America. Obesity Reviews, 19, 1028-1064.

https://doi.org/10.1111/obr.12694 
[66] Bingham, S.A., Welch, A.A., Mctaggart, A., et al. (2001) Nutritional Methods in the European Prospective Investigation of Cancer in Norfolk. Public Health Nutrition, 4, 847-858. https://doi.org/10.1079/PHN2000102

[67] Mercado, C.I., Cogswell, M.E., Valderrama, A.L., et al. (2015) Difference between 24-H Diet Recall and Urine Excretion for Assessing Population Sodium and Potassium Intake in Adults Aged 18 - 39 Y. The American Journal of Clinical Nutrition, 101, 376-386. https://doi.org/10.3945/ajcn.113.081604

[68] Freedman, L.S., Commins, J.M., Moler, J.E., et al. (2014) Pooled Results from 5 Validation Studies of Dietary Self-Report Instruments Using Recovery Biomarkers for Energy and Protein Intake. American Journal of Epidemiology, 180, 172-188. https://doi.org/10.1093/aje/kwu116 